\title{
Impact of Promotional Tools on Marketing of Library Services: An Exploratory Study of Polytechnics in Ghana
}

\author{
*Edward Asante ${ }^{1}$, Edward Markwei Martey ${ }^{2}$, Joseph Owusu Kwakye ${ }^{3}$
}

${ }^{1}$ Koforidua Technical University, Library Department

${ }^{2}$ Koforidua Technical University, Marketing Department

${ }^{3}$ Akrofi Christaller Institute of Theology, Mission and Culture

*eddieasante59@gmail.com

\begin{abstract}
The study investigates the impact of promotional tools on marketing of library services. The study explores the relationship between promotional tools constructs: personal selling, sales promotion, public relations and advertising on marketing of library services among selected Polytechnics in Ghana. With the aid of SPSS, the following statistical method were employed: supporting literature for measurement scales, values of cranach's alpha for construct values, descending means of constructs, skewness and kurtosis on the constructs, correlations and regression analyses on a sample of 402 obtained through convenience sampling method. The study revealed that, all the constructs of the promotional tools thus personal selling, sales promotion, public relations and advertising have significant positive relationship with marketing of library services. The study suggests that the professional training of library staff should include courses such as personal selling, sales promotion, public relations and advertising. . Library staff should be trained and develop skills on how to handle users request and establish a good personal relationship with users of the library. Library staff should be oriented on the procedures to handle complaints and find lasting sloutions to them. Users should be updated with the list of new databases, online services and new journals via notice board, leaflets and newsletters as well as the institutional websites. Library staff should collaborate with professional markerters on the application of the marketing mix in the promotion of their services.
\end{abstract}

Keywords: Advertising, Personal selling, Sales promotion, Public relations, Academic libraries

\section{Introduction}

The concept of marketing has been transferred from business to public service organizations. Since 1970, it has been seen that marketing principles can be applied to non-profit organizations like the library (Adeyoyin, 2005). In recent years, marketing has been important for reasons like self protection, the existence of competitors, an increase in customers' expectations, and wide access to information. Kotler and Fox (1995) provide the following definition of marketing in relation to higher education.

Marketing is the analysis, planning, implementation, and control of carefully formulated programs designed to bring about voluntary exchanges of values with target markets to achieve institutional objectives. Dodsworth (1998) believes that the changes in society have led to creation of opportunities and threats for libraries. Other surveys that show a majority of people using search engines in preference to library resources has been the cause of alarm among librarians who see libraries in danger of losing their place as an information provider (Fialkoff ,2006).

Academic libraries have found that users are unsatisfied with their collections and are at the same time unaware of library services. Williams (2006) believes academic libraries spend millions of dollars a year on both electronic resources and hard copies, 
yet many of them are underused and unknown to users. Ewers and Austen (2007) claim that if libraries want to be client-oriented, they should understand their clients' needs, their environment, their resources and strengths, and the social factors that influence users. Libraries should also identify their strength as a competitive business, employ and train staff in client relations and marketing (Aharony, 2009). Marketing is useful to university libraries to improve their image and to attract more users. Marketing helps librarians improve their reputation within their organizations and as a profession within society (Kendadamath, 2004).

An institutional library's resource should be readily available to users but it seems most library resources are partially used by the users, perhaps due to lack of awareness to the potential users. Due to high competition from other information providers, libraries must now adopt the new philosophy of marketing their services. Preliminary visit to some academic libraries suggests that much has not been put in place to meet the new philosophy of marketing library resources hence appearing difficult to the librarians. The old fashion of the librarian sitting stack to the chair is still dominant in some academic libraries especially in developing countries like Ghana. It seems there is lack of commitment on the side of the librarian with respect to the marketing of products and services of the library. The researchers have not seen any empirical research that critically examines the marketing of library services of selected Polytechnic libraries in Ghana. It is against this backdrop that the researchers consider it necessary to assess the marketing of library resources with specific emphasis on selected Polytechnic libraries in Ghana.

According to Hinson (2006) a service is an activity or series of activities of a more or less tangible nature that normally take place in interactions between the customer and the service employee or systems of the provider which are provided as solutions to customer needs or problems. Deducing from this definition, library services in this context means providing a series of activities such as charging and discharging, answering of queries, searching of information for users, guiding users to locate information either manual or electronic of a more or less tangible nature that usually occurs between the customer and the library personnel.

Kotler and Armstrong (2012) are of the view that marketing is the process companies create value for customers and build strong relationship in order to capture value from the customers in return. In another development, Boone and Kurtz (2006) define marketing as the process of planning and executing the conception, pricing and distribution of ideas, goods, organizations, and events to create and maintain relationship that will satisfy individual and organizational objectives. Though the library is a non - profit social institution, marketing of library services is of paramount importance in this technological era.

Rowley (2003) was of the view that, we need to encourage information professional to take a critical perspective on the nature and practice of marketing as it relates to information- based products and services. Anafo (2014) stresses the relevance of marketing in a non-delivery profit making establishment like the service library and points out the need for information workers to adopt some marketing strategies to get information to their clientele. These strategies include the concept of marketing, market segmentation, market analysis, marketing mix, market position and market audit (Anafo, 2014). There is therefore the need for libraries in Ghana to adopt these initiatives in order to ensure their continued use and importance. Failing this, the writer concludes that the continued survival and sustenance of libraries in Ghana is in jeopardy. According to Singh (2004) promotional tools are advertising, public relations, dissemination, sales promotion and personal selling.

Advertising is defined as any paid form of nonpersonal presentation and promotion of ideas, goods, or services, which has an identified sponsor. Polo et al (2011) indicated that advertising influence relationship between existing clients and service providers. Hyun et al (2011) also revealed that advertising induced emotional responses positively and perceived value. He indicates that four dimensions of advertising (relevant news, stimulation, empathy, and familiarity) significantly impact positively on inducing emotional responses. Bagwell (2005) examined the relationship between advertising and sales and found that there is no long run relation of advertising and the selling. Kamran (2012) in this study revealed that TV advertisement has a positive and significant effect on sales. Print media also shows positive impact on sales but the impact was insignificant. Moorthy (2005) suggests that consumers guess that high-quality products would advertise more than low-quality products. He 
provides substantial support for ad repetition that influences perceived quality.

Nowlis (2000) also proposes that sales promotions have effects on brand switching and aid in selecting promotional activity. A research conducted by Pwaels, Silva-Risso and Hanssens (2003) depicts the effect of sales promotion on firms' revenue. They reveal that sales promotion relates positively on top line performance but negatively on bottom line performance and firm's value. Elliott (2001) found that there is a long run positive effect of sales promotion on sales. Oyedapo et al (2012) concluded that engaging regularly in promotional mix strategies turns to enhance and boost their sales revenue. Kumar (2013) suggests that sales promotion could have strong negative effects on consumers' internal price reference and perceived quality and highlights the importance of integrating advertising with different promotional activities to improve the growth of sales of a product. Consumer promotional tools such as coupon affects consumers' choice and impacts on consumers' attitudes and intentions toward that brand (Laroche et al, 2005).

Personal selling is a strategy that salespeople use to convince customers to purchase a product. The salesperson uses a personalized approach, tailored to meet the individual needs of the customer, to demonstrate the ways that the product will benefit him. The customer is given the opportunity to ask questions, and the salesperson addresses any concerns he has about the product (Jerpi, 2000). Lin (2008) reveals that there is a sufficient link between choice of personal selling as a promotional tool and the collectivist orientation on the part of service provider. The results show that service providers who orientate towards collectivism in their cultural value structure will perceive personal selling as an important promotional tool and therefore, spend more of their promotion budget on personal communication tools such as personal selling and will continue to do so. Jackson et al (1994) explain that sales personnel can be evaluated based on product knowledge, sales presentation, communication and listening skills, teamwork, attitude, appearance and manners, initiative, and aggressiveness. It is recognized, however, that personal selling is a relatively expensive means of communication.

Taylor and Kent (2006) realized that public relation is about interacting and creating relationship with stakeholders. Taylor (2007) said public relations practitioners collect information and monitor public opinion from individuals, as well as regional, state and federal entities. Watson (2008) explains that public relations plays a major role in the strategic operation of organizations, by creating value through social capital and relationships. Al and Ries (2002) argue that advertising reaches limits that only public relations can surpass, mainly because public relations creates credible message. Vasileiou and Rowley (2011) explain that there are means to promote information services such as, sending of e-mail to library users, creating library websites and use of other social networking tools. Jose and Bhat (2007) indicated that the best way to promote information service is mouth-to-mouth and were affirmed by the findings of Vasileiou and Rowley (2011) that wordof-mouth is an influencing promotional tool.

A research conducted by Kumar (2008) on marketing and promotion of library services, employed research techniques including surveys, focus groups and suggested that librarians should be actively involved in marketing and promoting of library services. They must also appreciate and understand clients' needs and deliver what they need efficiently and effectively while fighting for better financial support.

According to Das and Kam (2008) who researched into marketing of library and information services in global era, a current approach revealed that the ultimate objective of the marketing of library and information services should be the dissemination of the right information to the right customer (user) at the right time and recommended the use of 5 Ps of marketing mix, i.e. product, pricing, place, promotion and person (staff) by librarians. Konya (2013) conducted a research into marketing communication in libraries: observations of German research libraries. In this study, the author analyzed marketing communication/promotion from the marketing mix applications. The study revealed that libraries have began to use marketing techniques in their applications recently and have made it possible to determine the kind of information their clients need. Figure 1 below shows the link between the promotional tools and marketing of library services. 


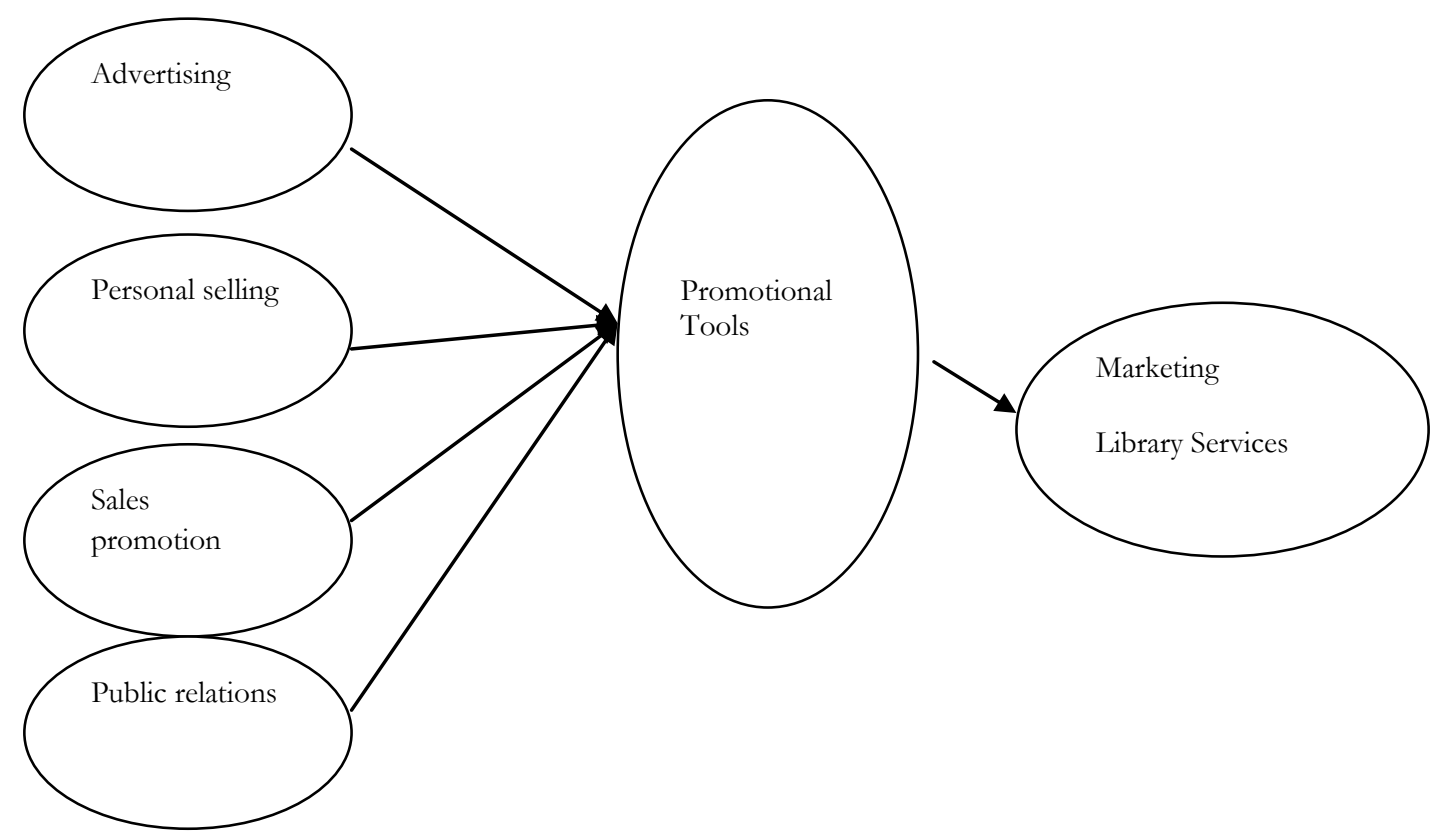

Fig 1. Link between promotional tools and marketing of library services Source: Authors own Contructs, 2015

\subsection{Research Hypotheses}

Based on the above review and research frame work, the hypotheses were designed as follows:

$\mathrm{H}_{1}$ : Advertising contributes positively to marketing of Library services

$\mathrm{H}_{2}$ : Personal selling contributes positively to marketing of Library services

$\mathrm{H}_{3}$ : Sales promotion contributes positively to marketing of Library services

$\mathrm{H}_{4}$ : Public Relations contributes positively to marketing of Library services

\subsection{Objectives of the Study}

The purpose of this study is to investigate the impact of promotional tools on marketing of Library services. The specific research objectives of the study are;

To assess the relationship between advertising and marketing of Library services

To investigate the relationship between personal selling and marketing of Library services
To identify the relationship between sales promotion and marketing of Library services

To investigate the relationship between public relations and marketing of Library services

\section{Methodology}

Descriptive survey design using quantitative paradigm was adopted for the study. Survey research design was used for the study because surveys have been identified as making it possible to collect large amounts of data from a sizeable population in a highly economical way (Saunders et al, 2009). The design was considered appropriate for the study as it enabled the questionnaires to be administered to participants with ease.

The questionnaire consisted of close and openended question items. The population of the study was users of library services between the age group of 18-55years in selected Polytechnics (Koforidua, Accra and Kumasi) in Ghana. These polytechnics were selected due to their proximity. The researchers 
pre-tested the questionnaire on potential library users from Takoradi Polytechnic a neighboring Polytechnic, before the actual distribution. Observed errors, corrections and re-wordings discovered were effected and incorporated into the main instrument. Convenience sampling method was adopted in distributing the questionnaire. The researchers distributed the questionnaire with the help of four (4) research assistants in May/June, 2015. Out of five hundred and thirty (530) copies of questionnaire distributed, four hundred and two (402) were returned fully filled.The sample size for the satudy was four hundred and two (402) 402.

The data collected was entered onto a computer using SPSS. The following statistics were used: Pearson correlation ( $r$ ) was used to determine the relationship among construct of promotional tools. According to Sekaran (2003) the correlation between two variables is considered a perfect positive correlation when it is close to +1 , or perfect negative correlation when it is close to -1 . Pearson correlation only shows the strength and direction of relationship. Regression analysis was undertaken in order to examine the correlation more closely and to examine the effects of the independent variables on the dependent variable. To test predictive relationships, personal selling, sales promotion, advertising and public relations, were used as the independent variables and marketing of library services used as the dependent variable.

\section{Results and Discussions}

Following the guidelines indicated in the research methodology, data was collected in 2014.

Table 1

Demographic information

\begin{tabular}{lll}
\hline Variables & $\begin{array}{l}\text { Frequency } \\
(\mathrm{n}=402)\end{array}$ & $\begin{array}{l}\text { Percentage } \\
(100 \%)\end{array}$ \\
\cline { 1 - 2 } Gender & 241 & 60.0 \\
\cline { 1 - 1 } Male & 161 & 40.0 \\
Female & & \\
Users & 225 & 60.0 \\
\hline Students & 56 & 13.9 \\
Lecturers & 61 & 15.1 \\
Administrators & & \\
& 30 & 7.5
\end{tabular}

Visit to Library

\begin{tabular}{lll}
\hline Everyday & 145 & 36.1 \\
Once a week & 117 & 29.1 \\
Twice a week & 123 & 30.6 \\
Once a semester & 17 & 4.2 \\
\end{tabular}

Source: field work, 2015

Table 1 show that $60.0 \%$ are females whiles the remaining $40.0 \%$ are males. In the case of the user's category 63.3 , \% was students, $13.9 \%$ are lecturers, $15.1 \%$ are administrators, and whiles $7.5 \%$ are other users. This indicates that the study captured more females than males. Also in terms of the users the research captured a significant number of students as compared to the other categories. Again with reference to the visits to the library, $36.1 \%$ indicated every day, 29.1\% mentioned once a week, 30.6\% indicated twice in a week whiles $4.2 \%$ visited the library once in a semester. This could be concluded that most student visit the library every day.

Table 2

Supporting literature for measurement scales.

\begin{tabular}{ll}
\hline Construct & Scales \\
\hline Advertising (AD) & {$[46,44]$} \\
Personal selling(PS) & $436,55]$ \\
Sales promotion (SP) & {$[49,46]$} \\
Public Relations (PR) & {$[58,49]$} \\
\hline
\end{tabular}

(Source: field work, 2015)

All of the measurement scales used, as indicated in Table 2, were based on previous research. Assuring the validity and reliability of the measures required supporting literature to validate the scales which were used in the research constructs. The service quality constructs was measured using the scales and indices included in the previous work of Singh (2004).

Table 3

Values of Cronbach's alpha for the research dimension

\begin{tabular}{ll}
\hline Construct & Value \\
\hline Advertising(AD) & 0,700 \\
Personal Selling(PS) & 0,703 \\
Sales Promotion (SP) & 0,708 \\
Public Relations (PR) & 0.796 \\
\hline (Source: field work, 2015)
\end{tabular}


A reliability test was carried out using Cronbach's alpha, which measures the internal consistency of a construct. The recommended minimum acceptable limit of reliability measure, as reported by Sekaran (2003) is 0.60 . As shown in Table 3 , all the constructs passed the reliability test.

Table 4

Descending means of the constructs promotional tools

\begin{tabular}{lll}
\hline Construct & Mean & $\begin{array}{l}\text { Standard } \\
\text { deviation }\end{array}$ \\
\hline Advertising(AD) & 4.202 & 0,776 \\
Personal selling (PS) & 4.101 & 0,754 \\
Sales promotion (SP) & 4.011 & 0,765 \\
Public Relations (PR) & 4.220 & 0.787 \\
\hline
\end{tabular}

(Source: field work, 2014)

The result shown in Table 4 indicates frequency and descriptive statistics used to determine the relative importance of each of the dimension. The service qualities shown in Table 4 have a mean above 4 . Therefore it concludes that all of constructs are of significant importance to the study.
Table 5

Skewness and Kurtosis for research constructs

\begin{tabular}{lll}
\hline Variables & Skweness & Kurtosis \\
\hline Advertising(AD) & -0.344 & -0505 \\
Personal selling (PS) & -0.302 & -0.06 \\
Sales promotion (SP) & -0.403 & -0.66 \\
Public Relations (PR) & -0.325 & -0.43 \\
\hline
\end{tabular}

(Source: field work, 2014)

From Table 5, Kurtosis and Skewness values were used to check the normality of each variable used in the research. Skewness value larger than $(+1)$ or smaller than $(-1)$, as suggested by Hair, Babin, Money \& Samouel (2003) indicate a substantially skewed distribution. Besides, Hair, Anderson, Tatham \& Black (1998) added that a curve is too peaked when the Kurtosis exceeds $(+3)$ and is too flat when it is below $(-3)$. This means Skewness values within the range of $(-1)$ to $(+1)$ and Kurtosis values within the range of $(-3)$ to $(+3)$ indicates an acceptable range. As shown in Table 5 , the values of Skewness and Kurtosis for each variable indicate that the research constructs fell within the acceptable range.

Table 6

Correlations analysis

\begin{tabular}{lllll}
\hline & AD & PS & SP & PR \\
\hline AD & 1 & $0146(.201)$ & $0.26(* *) .000$ & $001(.301)$ \\
PS & $0.146(.201)$ & 1 & $.002(*) .023$ & $.014(.223)$ \\
SP & $0.26(* *) .000$ & $.002(*) .023$ & 1 & $.120(.662)$ \\
PR & $001(.301)$ & $.014(.223)$ & $.120(.662)$ & 1 \\
\hline
\end{tabular}

** Correlation is significant at the 0.01 level (2-tailed). (Source: field work, 2014)

According to Table 6 it is clear that there is a strong positive relationship between the variables thus Advertising, Personal Selling, Sales Promotion and Public Relations .

Regression analysis was undertaken in order to examine the correlation more closely and to examine the effects of the independent variables on the dependent variable. To test predictive relationships, Advertising, Personal Selling, Sales Promotion and Public Relations value were used as the independent variables and Marketing Library Service was used as the dependent variable.
Table 7

Model summary

\begin{tabular}{llll}
\hline Model & $\mathrm{R}$ & R Squared & $\begin{array}{l}\text { Std. Error of } \\
\text { the Estimate }\end{array}$ \\
\hline 0.76 & 0.647 & 0.103 \\
\hline
\end{tabular}

(Source: field work, 2014)

The results of the multiple regression analysis, as shown in Table 7, $\mathrm{R}$ determine the correlation between promotional tool and Marketing Library Service. These explain that the correlation between the two variables is 0.076 which signify a strong positive relationship. Besides the result reveal a coefficient of determination, $\mathrm{R} 2$, which predicts the relationship between the independent variables and 
dependent variable, at 0.247 . This means that 64.7 percent of the total variance in the dependent variable (Marketing Library Service) is accounted for by the independent variables (Advertising, Personal Selling, Sales promotion and Public Relations). This result affirms that the four construct of promotional tools significantly contribute positively to marketing of library services.

Table 8

ANOVA result model

\begin{tabular}{llrrrrr}
\hline Model & & \multicolumn{1}{c}{$\begin{array}{l}\text { Sum of } \\
\text { Squares }\end{array}$} & Df & Mean Square & F & Sig. \\
\hline 1 & Regression & .425 & 4 & .435 & 87.04 & $.000(\mathrm{a})$ \\
& Residual & 75.052 & 175 & .542 & & \\
& Total & 75.477 & 179 & & & \\
& & & & & & \\
& & & & & & \\
& & &
\end{tabular}

a Predictors: (Constant), advertising, personal selling, sales promotion, public relations

b Dependent Variable: marketing library services

(Source: field work, 2014)

The results of the F-ratio, as shown in Table 8, indicates that the regression model is significant at $\mathrm{p}$ $<0.005$. It can be concluded, that the regression model can predict marketing library services. In other words, promotional tool construct: advertising,

Table 9

Results of Multiple Regression Analysis

\begin{tabular}{|c|c|c|c|c|c|c|}
\hline \multirow[b]{2}{*}{ Model } & & \multicolumn{2}{|c|}{ Unstandardized Coefficients } & \multirow{2}{*}{$\begin{array}{c}\begin{array}{c}\text { Standardized } \\
\text { Coefficients }\end{array} \\
\text { Beta }\end{array}$} & \multirow[b]{2}{*}{$\mathrm{T}$} & \multirow[b]{2}{*}{ Sig. } \\
\hline & & B & Std. Error & & & \\
\hline \multirow[t]{5}{*}{1} & (Constant) & 9.858 & 6.958 & & 4.417 & .000 \\
\hline & personal selling & -2.871 & 2.108 & .043 & 2.362 & .000 \\
\hline & Advertising & -.442 & .907 & .042 & 5.487 & .000 \\
\hline & sales promotion & 1.112 & 1.035 & .042 & 3.075 & .000 \\
\hline & public relations & -.900 & 1.019 & .044 & 3.883 & .000 \\
\hline
\end{tabular}

a. Dependent Variable: Marketing Library services

(Source: field work, 2014)

The regression analysis presented in Table 9 reveals that Marketing Library Services is contributed by promotional tools construct; advertising, personal selling, sales promotion, public relations. Personal selling has a beta value of 0.43 . This means that personal selling contributes $43 . \%$ of marketing of library's service, at a p-value of 0.00 .This explains personal selling, sales promotion, public relations value (the independent variables) do not have the ability to predict marketing library service (the dependent variable). that there is positive significant association of personal selling with Marketing Library Services. Advertising has a beta value of 0.42 . This means that advertising contributes 42 . \% of marketing of library's service, at a p-value of 0.00.This explains that there is a positive significant association of advertising with Marketing Library Services. 
Sales promotion has a beta value of 0.42 . This means that sales promotion accounted for $42 . \%$ of marketing of library's service, at a p-value of 0.00.This explains that there is a positive significant association of sale promotion with Marketing Library Services. Personal selling has a beta value of 0.44 . This means personal selling accounted for $44 . \%$ of

Table 10

Summary of the research hypotheses and their results

\begin{tabular}{|c|c|c|c|c|}
\hline Hypothesis & Description & Beta & t-value & Comment \\
\hline $\mathrm{H} 1$ & $\begin{array}{l}\text { Personal selling contributes positively to marketing of } \\
\text { Library services }\end{array}$ & 0.43 & 2.362 & Accepted \\
\hline $\mathrm{H} 2$ & $\begin{array}{l}\text { Advertising contributes positively to marketing of Library } \\
\text { services }\end{array}$ & 0.42 & 5.487 & Accepted \\
\hline H3 & $\begin{array}{l}\text { Sales promotion contributes positively to marketing of } \\
\text { Library services }\end{array}$ & 0.42 & 3.075 & Accepted \\
\hline $\mathrm{H} 4$ & $\begin{array}{l}\text { Public relations contributes positively to marketing of } \\
\text { Library services }\end{array}$ & 0.44 & 3.883 & Accepted \\
\hline
\end{tabular}

(Source: field work, 2014)

The study examines the impact of promotional tools on marketing Library services. The findings revealed that all the hypotheses formulated were accepted. These results are in congruent with that of Norton and Kwong's (2007) research which shows that advertising have a significant positive impact on the patronage of users. This is also supported by Nazish et al (2011) that promotion changes the perception of library users positively.

Yancey et al (2009) found that, library advertising using magazines, billboards, television, and radio have positive impact on the preference and decision making of users. Muhammad (2013) investigated the impact of promotional tools on user behavior and claimed that, a positive and significant relationship exit between the two variables. This means that if the Library spends more on promotional tools, they stand the chance of changing the behavior of their users positively.

Anderson and Simester, (2004) in a previous study found a negative impact of promotion on Library services because it increases the cost of running the library. Besides Bagwell (2005) examined whether there is any long-term stable relationship between advertising and marketing of Library services and found that, there is no long term relation between advertising and marketing of Library services. marketing of library's service, at a p-value of 0.00.This explains that there is a positive significant association of personal selling with Marketing Library Services. The above data shows that all the above hypothesized relationships between promotional tools and marketing Library services are accepted.

\section{Conclusion}

The study was the assessment of the impact of promotional tools on marketing of library services in an academic setting in a developing country like Ghana with specific emphasis on three Polytechnics namely (Koforidua, Accra and Kumasi). The study adopted the quantitative paradigm using questionnaire to elicit data and information for the study. All the four constructs of promotional tools thus personal selling, advertising, and sales promotion as well as public relations tested revealed a significant positive relationship with the marketing of library services.

\section{Recommendations}

Based on the findings of the study, the following recommendations were made:

1. Library staff should be trained and develop skills on how to handle users enquires and how to establish a personal relationship with users of the library. Library staff should be oriented on the procedures to handle complaints and find lasting sloutions to them..

2. Professional training of library staff should include courses in advertising, personal selling, sales promotion and public relations. Knowledge acquired in these courses will help the library staff to be 
able to communicate to users about the services avalible in the library.

3. There is the need for reliable and stable internet service for users to improve the library's image. Users should be updated with the list of new databases, online services and new journals via notice board, leaflets and newsletters as well as the institutional website. Library staff should respond quickly to emails and maintain up-to-date address list of user groups and customize the advertising message based on their respective needs.

4. Library staff should collaborate with professional markerters on the application of the marketing mix in the promotion of their servives.

\section{References}

Aharony, N.(2009) Librarians' attitudes towards marketing library services, 2009, Available: http://lis.sagepub.com/cgi/reprint/41/1/39. pdf

Al, R \& Ries L (2002). The fall of advertising and the rise of PR. New York: Harper Business.

Anafo, P.(2014) Marketing strategies for information services: a case study of the Institute of CharteredAccountants (Ghana) Library and InformationServices, Library Philosophy and Practice (e-journal).Paper 1033.

Anderson, E. T., \& Simester, D. I.(2004). Impact of promotion depth on new vs. established customers. Marketing Science , 23, 1, 4-20

Bagwell, K. (2007). The economic analysis of advertising. Handbook of industrial organization, 3, 17011844.

Boone. E. \& Kurtz, L.K. (2006) Principles of marketing $12^{\text {th }}$ ed, Ohio: Thomson: South-

Das, B. K., \& Karn, S. K. (2008). Marketing of library and information services in global era: a current approach. Webology, 5 (2)

Dodsworth, E. (1998) Information polices marketing academic libraries: a case necessary plan, "Journal of Academic librarianship, 24(4), p.320322

Ewers,B. \& Austen G. (2004) Market Orientation: A framework for Australian University Library

Hair J . Babin. B, Money. A \& Samouel .P,(2003) Essentials of business research methods, Lehigh Publishing.

Hair J, Anderson R, Tatham R \&. Black W,(1998) Multi- Variate Data Analysis, 5thEdition, Prentice-Hall, Upper Saddle River, 1998.
Hinson, R. (2006) Marketing of Services: A managerial perspective. Accra: Sedco-LongmanInstitute of Chartered Accountants (Ghana) Library and Information Services"

Jackson, D. W., Tax, S.S. \& Barnes J.W. (1994). Examining the salesforce culture: managerial applications and research propositions. Journal of Personal Selling and Sales Management, 14 (4): 1-14

Kendadamath, G.C. (2004) Marketing of library \& information Services, Available: http://www.bhu.ac.in/InstituteofAgricultural SciencesBHU/EXTENSION_EDUCATIO N/Winter\%20School/WS_13.pdf

Konya U (2013) Marketing communication in libraries: observations of German research libraries. Qualitative and Quantitative Methods in Libraries (QQML) 2,149 - 156

Kotler, P. \& Fox, K.A.,(1995) Strategic Marketing for Educational Institutions, (Prentice Hall, Englewood Cliffs, NJ,

Kotler, P.\& Armstrong, G.(2012) Principles of Marketing $14^{\mathrm{TH}}$ ed, Boston: Pearson Education

Kumar, C, Mosharraf H, Farhad H. A.(2013) Effects of sales promotion and advertising on consumer's purchase, World Journal of Social Sciences Vol. 3. No. 4. Pp. 183-194

Moorthy.\& Hawkins, S.A.(2005), 'Advertising repetition and quality perception, Journal of Business Research,Vol.58, pp. 354-360.

Muhammad R.(2013)The Impact of promotional tools on consumer buying behavior: A study from Pakistan Asian Journal of Empirical Research, , Vol. 3, (2), pp 114-130.

Nazish,S., Rizvi,Z,\& Malik,S. (2011) Impact of sales promotion on organizations' profitability and consumer's perception in Pakistan. Interdisciplinary Journal of Contemporary Research in Business, Vol 3, No. 5 p1-50.

Norton, E. C. \& Kwong, W. J. (2007). The effect of advertising on pharmaceutical innovation. Review of Industrial Organization, 31(3), 221-236

Nowlis, S.M.\& Simonson, I.(2000), 'Sales promotions and the choice context as competing influences on consumer decision making, Journal of Consumer Psychology, Vol.9(1), pp. 116.

Oyedepo, W. O.,.Akinlabi B. H. \& Sufian J. B.(2012 )The impact of sales promotion on organization effectiveness in Nigerian manufacturing industry .Universal Journal of 
Marketing and Business Research. Vol. 1(4), pp. 123-131.

Patton, B.A.(2002). International students and the American University Library'. ERIC Document No.ED469 810, p.132, 2002

Rowley, J. (2003) Information marketing: seven questions. Library Management Service. Vol. 24, pp. 13-19.

Saunders, M., Lewis, P. and Thornhill, A. (2009), Research Methods for Business Students , Pearson Education, London

Sekaran, U. (2003). Research Methods for Business, a Skill Building Approach. $4^{\text {th }}$ edition. Wiley, New York.

Singh, J. (2000). Performance productivity and quality of frontline employees in service organizations. Journal of marketing, 64 (2), 1534.
Taylor, M \& Kent, M.L (2006). Puplic relations theory and practice in nation building. In C.H. Botan \& V. Hazleton (Eds), public relation theory II (pp 299-315). Mahwah, NJ: Enbaum.

Vasileiou, M., \& Rowley, J. (2011). Marketing and promotion of e-books in academic libraries. Journal of documentation, 67(4), 624-643.

Watson T, (2008).Public relations research priorities: a Delphi study. Journal of CommunicationWestern

Williams, L. (2006) Making 'E' Visible, Library Journal, 13(1),11 p. 40-43.

Yancey, A. K., Hillier, A., Cole, B. L., Smith, T. E., Williams, J. D., Grier, S. A., \& McCarthy, W. J. (2009). Clustering of unhealthy outdoor advertisements around child-serving institutions: a comparison of three cities. Health \& Place, 15(4), 935-945. 